\title{
EVALUATION OF PHYTOCHEMICAL CONSTITUENTS AND ANTIMICROBIAL ACTIVITY OF SILVER NANOPARTICLE SYNTHESIZED IPOMOEA NIL AGAINST SELECTED PATHOGENS
}

\author{
ASHA $\mathbf{S}^{1 *}$, ASHA A ${ }^{1}$, RAJESHKUMAR $\mathbf{S}^{2}$ \\ ${ }^{1}$ Department of Biochemistry, D.K.M. College for Women (Autonomous), Sainathapuram, Vellore, Tamil Nadu, India. ${ }^{2}$ School of Bio-Sciences \\ and Technology (SBST), VIT University, Vellore, Tamil Nadu, India. Email: asha.sivaji@gmail.com
}

Received: 01 November 2016, Revised and Accepted: 28 November 2016

\section{ABSTRACT}

Objective: The objective of this study is to investigate a simple and feasible approach for the production of silver nanoparticles (AgNPs) by using leaf extract of Ipmoea nil and to evaluate its antibacterial activity.

Methods: The AgNPs synthesized was characterized by a change in color and the absorption peaks by ultraviolet-visible spectroscopy. The phyto compounds responsible for the reduction and capping of silver ions was known from Fourier transform infrared spectra and phytochemical analysis. The antibacterial effects of prepared aqueous AgNPs were detected against five types of pathogenic bacteria, including Gram-negative and Grampositive bacteria (Escherichia coli, Salmonella, Bacillius, Proteus, and Klebsilla pneumonia) using agar well diffusion method.

Results: A peak absorption value between 400 and $450 \mathrm{~nm}$ and the color change of the extract from yellowish to red wine were corresponds to the plasmon absorbance of AgNPs. On the other hand, aqueous extract of I. nil mediated AgNPs found to be effective against tested microorganisms (Salmonella, Bacillus, and Proteus) with inhibition zone in the range of $10-13 \mathrm{~mm}(20 \mu \mathrm{l}$ and $10 \mu \mathrm{l})$ except E. coli and K. pneumonia. Furthermore, aqueous extract of $I$. nil leaves had no ability to suppress the growth of the tested microorganisms in the concentration of $10 \mu$ l. The control also produced similar inhibition zones like AgNPs.

Conclusions: Our findings indicated that green synthesized AgNPs mediated by I. nil leaf extract had an efficient anti-bactericidal activity against the bacterial species tested. Hence, further studies are needed to highlight its mechanism and application as an antibacterial agent.

Keywords: Ipomoea nil, Silver nanoparticles, Antibacterial activity, Bacteria.

(c) 2017 The Authors. Published by Innovare Academic Sciences Pvt Ltd. This is an open access article under the CC BY license (http://creativecommons. org/licenses/by/4. 0/) DOI: http://dx.doi.org/10.22159/ajpcr.2017.v10i3.15986

\section{INTRODUCTION}

Advancement in nanotechnology and biotechnology has emerged into the biosynthesis of nanoparticles. A great deal of struggle has been laid into the biosynthesis of nanoparticles, especially metal nanoparticles. Metal nanoparticles were synthesized using microorganisms and plants [1-3]. Among metal nanoparticles, silver nanoparticles (AgNP) have many important applications (Jain et al., 2008). AgNP has attracted enormous interest because of its wide applications in food, cosmetic, clothing, and pharmaceutical industries [4-6], medical implants, textile industries, water treatment, and as antimicrobial agents [7]. Various strategies carried out for a synthesis of AgNPs [8] are reduced [9], thermal decomposition [10], microwave-assisted synthesis [11], laser-mediated synthesis [12], and biological reduction method [13]. Even though these methods effectively yield AgNPs in a useful manner, it commonly comprises the practice of toxic and hazardous chemicals, found to have numerous destructive effects on the environment and human well-being [14]. The final product, thus obtained requires more purification steps since some of the chemicals or reducing agents or by-products left behind without use during the process gets adsorbed to the nanoparticle surface and leads to adverse effects during its application. Furthermore, these methods utilize luxurious chemicals and generally require stabilizers to avoid accumulation of chemicals on the surface of nanoparticles. On the other hand, a preferred way for the synthesis of nanoparticles is green chemistry, a widely accepted alternative process for synthesizing nanoparticles.

According to Ayurveda (an ancient Indian medical treatise), Nano silver is a popular additive in several Indian health products due to its unique ability to fight infectious diseases [15-18]. On the other hand, SNPs is gaining more importance in the medical field as antimicrobials, sterilizers, and testing tools for diagnosing and detecting sensitive biomolecules.

According to a literature review, various medicinal plants have been reported for the green synthesis of AgNPs such as Bryophyllum sp., Cyperus sp., Hydrilla sp. [19], Gliricidia sepium [20], Rosa rugosa [21], Cycas [22], Acalypha indica [23], Garcinia mangostana [24], Cocos nucifera coir [25], G. sepium [20], A. indica [26], Capsicum annuum [27], Carica papaya [28], and Eucalyptus hybrida [29].

Plants offer a highly appropriate system for nanoparticle synthesis over other methods due to their ability to produce nanoparticles in a single step, cost-effective, and eco-friendly manner [30] besides the presence of wide range of secondary metabolites. Subsequently, plants are not as much of sensitive toward metal toxicity when compared to algae and bacteria. Hence, medicinal plants offer a green alternative for the AgNPs biosynthesis [31] by providing capping layers to nanoparticles. Recently, green synthesis of nanoparticles is an exciting branch evolving in the field of nanotechnology Coriandrum sativum [32], A. indica [33] and Rhizophora mucronata [34].

In the present work, we synthesized a stable AgNPs using aqueous Ipomoea nil leaf extract and investigated its antibacterial activity against selected bacterial strains.

\section{MATERIALS AND METHODS}

Materials

The chemical silver nitrate $\left(\mathrm{AgNO}_{3}\right)$, Mueller-Hinton agar (MHA) for antibacterial study and ampicillin antibiotic were purchased from Sigma Chemical Co. 
$2 \mathrm{mM} \mathrm{AgNO}_{3}$ solution

$2 \mathrm{mM} \mathrm{AgNO}_{3}$ solution was prepared by dissolving $0.0339 \mathrm{~g}$ in $100 \mathrm{ml}$ double distilled water. The solution is mixed thoroughly in the dark and stored in an amber colored bottle for further use.

\section{Preparation of plant extract}

The plant under study (I. nil) was collected from in and around the Vellore District, Tamil Nadu, authenticated, and deposited in the herbarium. $10 \mathrm{~g}$ of fresh leaf of I. nil was separated from plant sample and cut into fine pieces using a knife. To this add $100 \mathrm{~mL}$ of double distilled water and boil for 10 minutes. The boiled solution was filtered through Whatman filter paper No.1 until a clear solution was obtained.

\section{Synthesis of AgNPs}

$2 \mathrm{mM}$ concentration of an aqueous solution of $\mathrm{AgNO}_{3}$ prepared was used for the synthesis of AgNPs. $30 \mathrm{ml}$ of I. nil leaves extract was added into seventy milliliter of an aqueous solution of $2 \mathrm{mM} / \mathrm{L}, \mathrm{AgNO}_{3}$ solution for the reduction into Ag+ ions. The solution was heated on a water bath at $80^{\circ} \mathrm{C}$ for 10 minutes. The change of color takes place within ten minutes from yellow to red wine. The solution was kept undisturbed for $24 \mathrm{hrs}$. The AgNPs were collected by centrifugation $10,000 \mathrm{rpm}$ twice for 10 minutes to collect pellets and were used for further studies.

\section{Characterization of AgNPs}

\section{Ultraviolet-visible (UV-VIS) spectroscopy}

UV-VIS spectral analysis of synthesized AgNPs was analyzed using UVVIS spectrophotometer from 300-500 nm range at a resolution of $1 \mathrm{~nm}$.

\section{Fourier transform infrared (FT-IR) spectral analysis}

I. nil extract and pellets of $I$. nil AgNPs were subjected to FT-IR analysis. FT-IR spectrometer identifies the active biomolecules linked to extract and AgNPs. The equipment was operated with a resolution of $4 \mathrm{~cm}^{-1}$ and scanning range of $500-4000 \mathrm{~cm}^{-1}$.

\section{Phytochemical screening}

Both the plant extract and the AgNPs were subjected to preliminary phytochemical analysis as per the standard procedure.

1. Test for carbohydrates

a. Molisch's test

To the test solution $1 \mathrm{ml}$ of alpha naphthol was added, followed by $1 \mathrm{ml}$ of concentrated sulphuric acid slowly along the sides of the test tubes. Keep the test tubes to stand in the room temperature. A violet ring at junctions of two liquids indicates the presence of carbohydrates.

2. Test for protein and amino acid

b. Biuret test

To the test solution $1 \mathrm{ml}$ of biuret reagent was added. A violet or pink colouration represents the presence of protein.

c. Ninhydrin test

$2 \mathrm{ml}$ of $5 \%$ ninhydrin solution was added into the test solution and heated for 10 minutes in a boiling water bath. The appearance of purple or bluish color indicates the presence of amino acids.

3. Test for alkaloids

d. Mayer's test

Test solution was taken in a separate test tube and each tube $1 \mathrm{ml}$ of Mayer's reagent was added, along the sides of the test tube. A white creamy or yellow coloration indicates the positive result to alkaloids.

e. Hager's test

$1 \mathrm{ml}$ of Hager's reagent was added to the test solution, and the prominent yellow precipitate indicates the presence of alkaloids.

4. Test for Saponin

f. Foam or froth test

$1 \mathrm{ml}$ of test solution was diluted with $20 \mathrm{ml}$ of distilled water and shaken for 15 minutes vigorously. A permanent foam or froth stable for 10 minutes depicts the saponin presence.
5. Test for Tannin and Phenolic compounds

g. Ferric chloride test

To few $\mathrm{ml}$ of the test solution, few drops of neutral $5 \%$ ferric chloride solution were added and heated in a boiling water bath. A color change indicates the phenolic compound presence.

h. Lead acetate test

$3 \mathrm{ml}$ of $10 \%$ lead acetate solution was added to $2 \mathrm{ml}$ of test solution; a bulky white precipitate confirmed the presence of both phenolic and tannin compounds.

6. Test for steroid and terpenoids

i. Salkowski's test

$2 \mathrm{ml}$ of chloroform and $2 \mathrm{ml}$ of concentrated sulfuric acid was added to test solution and shaken well. Allow the test tube to stand at room temperature. Lower layer with red color indicated the presence of steroids and an upper layer with golden color confirmed the presence of triterpenoids.

7. Test for glycosides

j. Borntrager's test

$5 \mathrm{ml}$ of chloroform and test solution was mixed and shaken well. To this, $10 \%$ ammonia solution was added. Pink color indicated the presence of anthraquinone glycosides.

Screening of the antibacterial property in synthesized nanoparticles

The AgNPs synthesized using I. nil leaves extract, aqueous extract of I. nil, ampicillin antibiotic was tested for antimicrobial activity by agar well diffusion method against different pathogenic microorganisms Escherichia coli, Salmonella sp., Bacillius sp., Proteus sp., and Klebsilla pneumonia. The pure cultures of bacteria strain microorganisms were sub-cultured on MHA medium. A sterile cotton swab was used to spread the microorganisms uniformly onto the individual plates and allowed to dry for 10 minutes. Subsequently, 4 wells were made on nutrient agar plates using a sterile metal cup-borer. Using a micropipette, $20 \mu \mathrm{l}$ and $10 \mu \mathrm{l}$ of nanoparticle solution, $10 \mu \mathrm{l}$ of aqueous extract of $I$. nil, and $10 \mu \mathrm{l}$ of standard antibiotic ampicillin were poured onto respective well on all plates. The plates were allowed to incubate at $37^{\circ} \mathrm{C}$ for $24 \mathrm{hrs}$. The diameter of zone of inhibition was measured in millimeter, the area surrounding the hole with no growth of inoculated microorganisms was recorded as an inhibitory effect against pathogens.

\section{RESULT}

In the present work, AgNPs has been biologically synthesized using fresh leaves of I. nil. Synthesis of AgNPs from colourlessAgNO $\mathrm{An}_{3}$ solution using leaves of $I$. nil was recognized by the color change of the solution (Fig. 1). Preliminary identification of nanoparticle formation was carried out by observing the color change of the reaction solution from colorless to red wine.

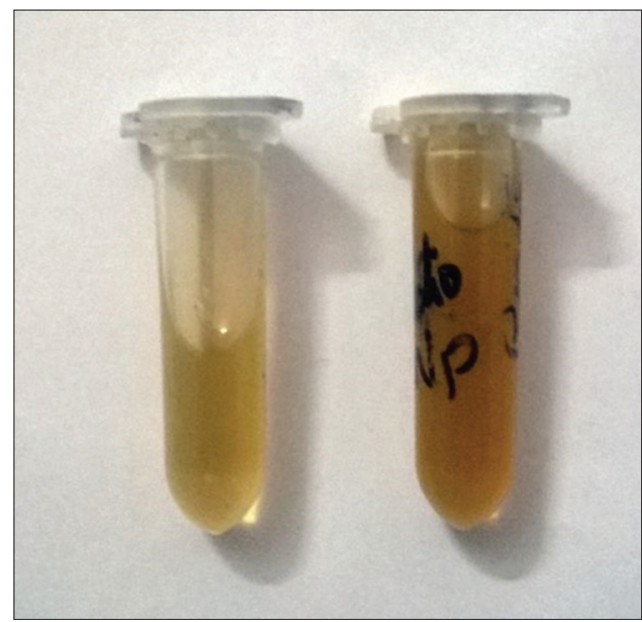

Fig. 1: Leaf extract of Ipomoea nil and synthesized nanoparticles 
The freshly prepared I. nil aqueous extract was yellowish in colour. However, after adding of colourlessAgNO $\mathrm{An}_{3}$ to aqueous extract and subsequent boiling, the suspension turned red wine. Formation of AgNPs was confirmed using UV-VIS spectroscopy. UV-VIS spectroscopy study monitors the process of reduction of silver ions to AgNPs, and the spectral analysis showed the plasmon resonance band between 400 and $450 \mathrm{~nm}$. The obtained UV-VIS spectral analysis was similar to previous reports reported by other workers $[35,36]$.

\section{FT-IR spectroscopy analysis}

It has been reported [27] in literature that plant constituents involved in the reduction and capping of nanoparticle can be identified by FT-IR technique. FT-IR measurements were taken to identify the possible biomolecules responsible for capping and efficient stabilization of the AgNPs synthesized by I. nil leaves. Figs. 2 and 3 shows the FT-IR spectra of leaf extract of $I$. nil and synthesized AgNPs overlay.

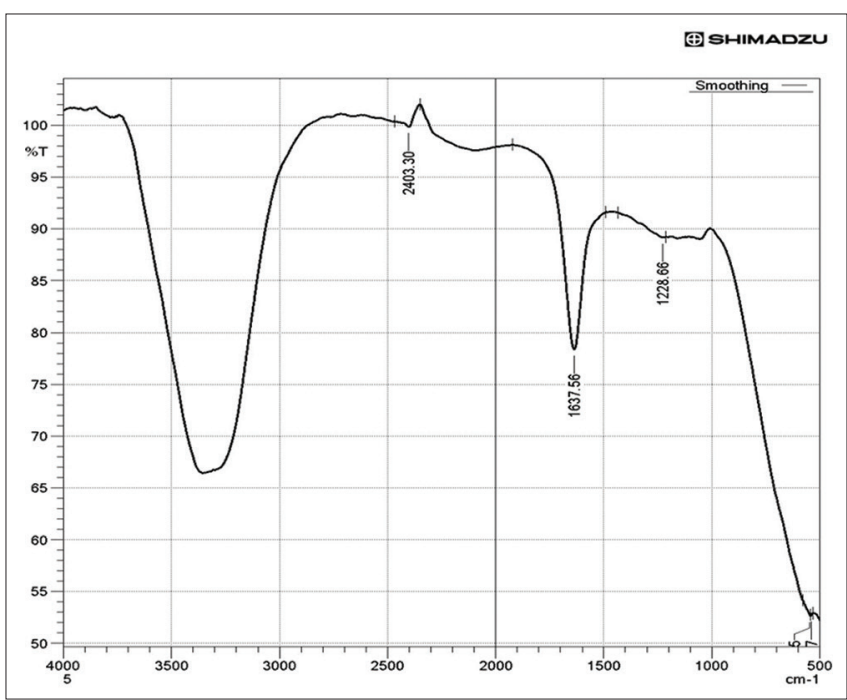

Fig. 2: Fourier Transform infrared spectrum of Ipomoea nil aqueous extract

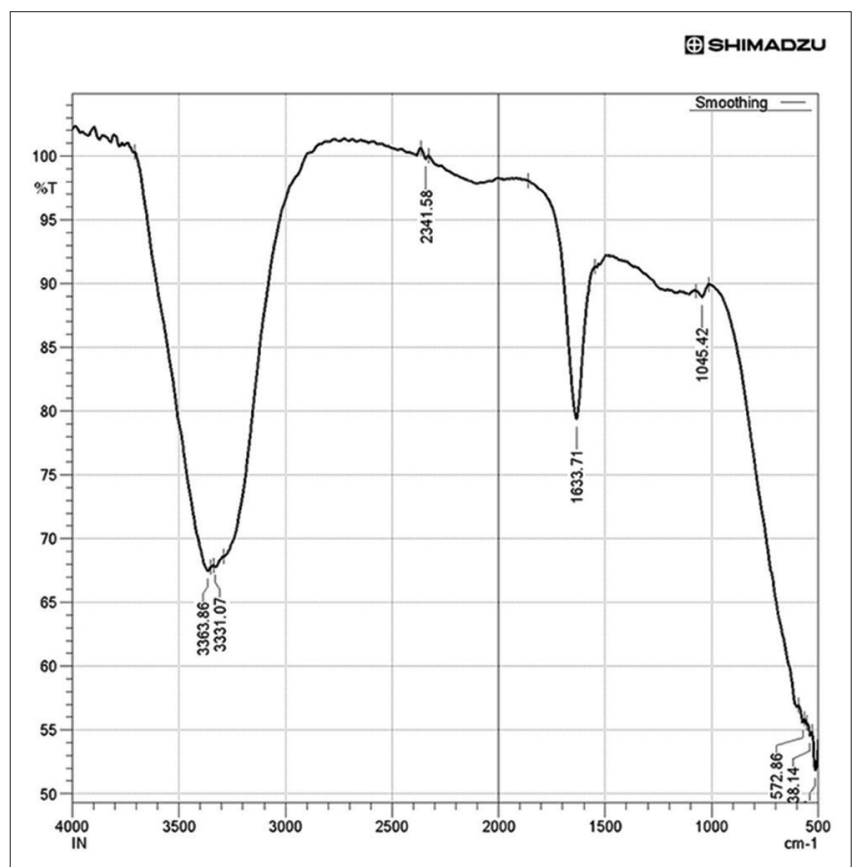

Fig. 3: Fourier Transform infrared spectrum of silver nanoparticle
FT-IR spectra of plant extract obtained showed absorption bands located at $1228.66,1637.56$, and $2403.30 \mathrm{~cm}^{-1}$.The absorption peak at around $1228.66 \mathrm{~cm}^{-1}$ can be assigned as absorption peak of C-C,C$\mathrm{N}, \mathrm{C}-\mathrm{O}$. The peak at around $1637.56 \mathrm{~cm}^{-1}$ is assigned to the functional group $\mathrm{C}=\mathrm{O}$. The peak at $2403.30 \mathrm{~cm}^{-1}$ indicates the presence of $\mathrm{O}-\mathrm{H}$ group in the extract.

The silver nanoparticles FT-IR spectra showed an absorption peaks at $1047.35,1109.07,1635.64,2360.87,3363.86,3730.33$, and $3801.70 \mathrm{~cm}^{-1}$ which corresponds to peaks in plant extracts.The chemical shift from $1637.56 \mathrm{~cm}^{-1}$ to 1635.64 and shift from 2403.30 to $2360.87 \mathrm{~cm}^{-1}$ indicates the reduction of silver ions and the capping of bioreduced silver nanoparticles synthesized by leaf extract of $I$. nil.

\section{Phytochemical analysis}

The phytochemical analysis of an aqueous extract of $I$. nil detected the presence of alkaloids, saponin, tannin, phenol, and glycosides while steroid and phenol were not found in aqueous extract. Secondary constituents such as alkaloids and flavonoids components were found in I. nil synthesized nanoparticles. Whereas saponin, tannin, phenol, and glycosides were absent in the synthesized AgNP (Table 1).

From the FT-IR spectrum and phytochemical analysis results, the component responsible for the reduction of silver ions and capping of AgNPs were identified as phenolic compound.

\section{Antibacterial activity}

In the present study, the antibacterial activity of AgNPs against various pathogenic organisms (E. coli, Salmonella, Bacillius, Proteus and K. pneumonia) were investigated. At $2 \mathrm{mM} / \mathrm{L}$, concentration of AgNPs, the $12 \mathrm{~mm}$ inhibitory zone appeared around $20 \mu \mathrm{l}$ against Salmonella sp. after incubation for $24 \mathrm{hrs}$ followed by bacillus sp., and proteus sp., (11 $\mathrm{mm}$ and $10 \mathrm{~mm}$, respectively), then $13 \mathrm{~mm}$ for salmonella and Proteus sp. at $10 \mu \mathrm{l}$ concentration. It is noted that there is no effect towards the growth of E. coli and Klebsiella. Control also produced a similar antibacterial activity toward bacteria as like AgNPs with a zone of inhibition of $31 \mathrm{~mm}$ (Salmonella), $17 \mathrm{~mm}$ (Proteus sp.,) and $11 \mathrm{~mm}$ (Bacillus sp.,). From the obtained zone of inhibition of $I$. nil aqueous extract, it was known at the extract at $10 \mu \mathrm{l}$ concentration does not have any inhibitory effect on selected bacterial strains. The data suggest that the synthesized nanoparticles at $10 \mu \mathrm{l}$ and $20 \mu \mathrm{l}$ had pronounced a good antibacterial action against pathogens compared to aqueous extract alone. The results of the antibacterial activity of AgNPs, aqueous extract and control against tested microorganisms are shown Fig. 4.

\section{DISCUSSION}

The development of comfortable, consistent and eco-friendly methods increase the interest in the nanoparticles synthesis and application $[35,36]$. On exposure to plant extracts, reduction of silver ions into AgNPs could be noticed by color change. AgNPs exhibited reddish-wine color in aqueous solution due to the surface plasmon resonance phenomenon [23].

Table 1: Phyto chemical investigation of leaf extract Ipomoea nil and its AgNPs

\begin{tabular}{lll}
\hline Test & Plant extract & AgNPs \\
\hline Test for tannins (lead acetate) & + & - \\
Test for saponin's (foam froth) & + & - \\
Test for flavonoids (sodium hydroxide) & - & + \\
Test for steroids (Salkowski) & - & - \\
Test for alkaloids (wagner and hager) & + & + \\
Test for phenol (lead acetate) & + & - \\
Test for glycoside (Bontrager) & + & - \\
\hline
\end{tabular}

+: Indicates presence, -: Indicates absence, I. nil: Ipomoea nil, AgNPs: Silver nano particles 


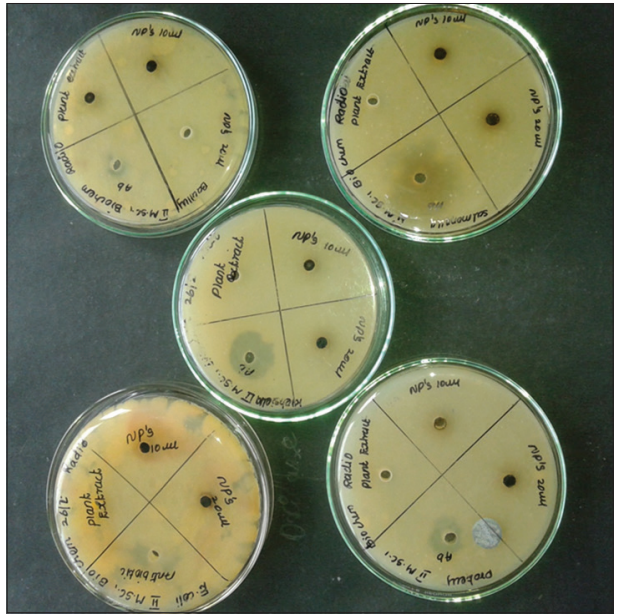

Fig. 4: Antibacterial activity

The production of the AgNPs from the leaf aqueous extract of I. nil was evaluated through UV-VIS spectrophotometry at a wavelength range of 300-600 nm [37]. The characteristic peak for I. nil AgNPs at 400 to $450 \mathrm{~nm}$ confirmed the formation of the AgNPs. The obtained UV-VIS spectral analysis was similar to previous reports reported by other workers [38-40]. This is similar to the surface plasmon vibrations with characteristic peaks of the AgNPs prepared by Eucalyptus hydrida, Securinega leucopyrus, A. indica [29,41,42], Eucalyptus chapmaniana, Eucalyptus hybrid and Eucalyptus globulus $[40,43,44]$. The result obtained in this investigation is very interesting in terms of the identification of potential medicinal plants for the synthesis of AgNPs.

Furthermore, the antibacterial activity of biologically synthesized AgNPs was investigated against five human pathogens and results exhibited a good antibacterial activity against tested bacteria. However, the antibacterial effect varied according to the bacterial strains [45]. In addition, the AgNPs showed good inhibition activity towards Salmonella (13 $\mathrm{mm}$ and $12 \mathrm{~mm}$ for $20 \mu \mathrm{l}$ and $10 \mu \mathrm{l}$, respectively), Proteus $(13 \mathrm{~mm}$ and $10 \mathrm{~mm}$ for $20 \mu \mathrm{l}$ and $10 \mu \mathrm{l})$, and Bacillus $(12 \mathrm{~mm}$ and $10 \mathrm{~mm}$ for $20 \mu \mathrm{l}$ and $10 \mu \mathrm{l})$ in a dose-dependent manner. E. coli and Klebsellia sp. does not show any inhibitory effect against synthesized AgNPs. The water extract of $I$. nil when applied does not find to have effective activity against all tested bacterial strains. Thus, the ability to suppress the microbial growth was higher in AgNPs when compared to aqueous extract. Despite its action, the mechanism of action on microorganism is incompletely known. However, some previous reports suggested the inhibitory action of AgNPs may be due to its smaller size and capacity to enter into the bacterial cell. After the entry into the bacterial cell, the silver ions affect the intracellular processes such as DNA, RNA, and protein synthesis $[46,47]$. It was suggested that the inhibitory action of silver ions (particularly $\mathrm{Ag}^{+}$) released from AgNP might be able to interact with sulfur-containing proteins and phosphorus moieties in DNA, a key element for the antimicrobial effect. This leads to the inhibition of enzyme function and inactivation of DNA replication process and eventually results in loss of cell viability and finally led to cell death [48-51].

This antibacterial ability of AgNPs might be due to the reduction of phenol, glycosides, saponin, and tannins present in the leaf extract [52]. The occurrence of tannins, saponins, alkaloids, phenol and glycosides in the leaf extract of $I$. nil was reported. This preliminary finding was similar to the presence of phytoconstituents as reported in aqueous extract of Eucalyptus camaldulensis, Terminalia glaucescens and Rhynchotechumellipticum [53-55]. AgNPs showed higher ability to suppress the microbial growth, which was pronounced against both Gram-positive bacteria and Gram-negative bacteria. The current investigation demonstrated that the biosynthesized AgNPs had an excellent antibacterial activity against some Gram-positive and Gramnegative bacteria.

\section{CONCLUSION}

It has been demonstrated that the aqueous extract of $I$. nil leaves is capable of producing AgNPs in a fast, green, economical method, and the AgNPs produced are relatively stable in solution. Basically, the synthesis of nanoparticle is carried out by the reduction process. In the case of phytochemical analysis result plant extracts containing tannins, saponins, phenol, and glycosides are responsible for the synthesis of nanoparticles. Based on the FT-IR spectrum reports, the phenolic compound is majorly responsible in the synthesis of nanoparticles. The biosynthesized AgNPs showed excellent antibacterial activity and the data represented in our study contribute to a novel and unexplored area of nano-materials as alternative medicine. Therefore, further studies are needed to fully characterize the mechanisms involved with the antibacterial activity of these particles.

\section{REFERENCES}

1. Mohanpuria PN, Yadav SK. Biosynthesis of nanoparticle, technological concepts and future applications. J Nanopart Res 2007;7:9275.

2. Farooqui MA, Chauhan PS, Krishnamoorthy P, Shaik J. Extraction of silver nano-particles from the leaf extracts of Clerodendrum inerme. Dig J Nanomater Biostruct 2010;5:43-9.

3. Jain PK, Huang XH, El-Sayed IH, El-Sayed MA. Noble metals on the nanoscale: Optical and photothermal properties and some applications in imaging, sensing, biology, and medicine. Acc Chem Res 2008;41:1578-86.

4. Ahamed M, Alsalhi MS, Siddiqui MK. Silver nanoparticle applications and human health. Clin Chim Acta 2010;411(23-24):1841-8.

5. Marambio-Jones C, Hoek EM. A review of the antibacterial effects of silver nanomaterials and potential implications for human health and the environment. J Nanopart Res 2010;12(5):1531-51

6. Rai M, Kon K, Ingle A, Duran N, Galdiero S, Galdiero M. Broadspectrum bioactivities of silver nanoparticles: The emerging trends and future prospects. Appl Microbiol Biotechnol 2014;98(5):1951-61.

7. Sharma VK, Yngard RA, Lin Y. Silver nanoparticles: Green synthesis and their antimicrobial activities. Adv Colloid Interface Sci 2009; $145(1-2): 83-96$.

8. Tolaymat TM, El Badawy AM, Genaidy A, Scheckel KG, Luxton TP, Suidan M. An evidence-based environmental perspective of manufactured silver nanoparticle in syntheses and applications: A systematic review and critical appraisal of peer-reviewed scientific papers. Sci Total Environ 2010;408:999-1006.

9. Guzman MG, Dille J, Godet S. Synthesis of silver nanoparticles by chemical reduction method and their antibacterial activity. Int J Chem Biol Eng 2009;2:10411.

10. Navaladian S, Viswanathan B, Viswanath R, Varadarajan T. Thermal decomposition as route for silver nanoparticles. Nanoscale Res Lett 2006;2:44-8

11. Sreeram KJ, Nidhin M, Nair BU. Microwave assisted template synthesis of silver nanoparticles. Bull Mater Sci 2008;31:937-42.

12. Zamiri R, Zakaria A, Abbastabar H, Darroudi M, Husin MS, Mahdi MA. Laser-fabricated castor oil-capped silver nanoparticle. Int J Nanomed 2011;6:565-8.

13. Sastry M, Ahmad A, Khan MI, Kumar R. Biosynthesis of metal nanoparticles using fungi and actinomycete. Curr Sci 2003;85:162-70.

14. Rani PU, Rajasekharreddy P. Green synthesis of silver-protein (core-shell) nanoparticles using Piper betle L. leaf extract and its ecotoxicological studies on Daphnia magna. Colloids Surf A 2011;389:188-94.

15. Pal D, Sahu CK, Haldar A. Bhasma: The ancient Indian nanomedicine. J Adv Pharm Technol Res 2014;5:4-12.

16. Chaudhary A. Ayurvedic bhasma: Nanomedicine of ancient India - its global contemporary perspective. J Biomed Nanotechnol 2011;7:68-9.

17. Sanjoy KP. The Ayurvedic Bhasma: The ancient science of nanomedicine. Rec Pat Nanomed 2015;5:12-8.

18. Panda H. Handbook on Ayurvedic Medicines with Formulae, Processes and Their Uses. India: National Institute of Industrial Research; 2004. p. 10.

19. Jha AK, Prasad K, Prasad K, Kulkarni AR. Plant system: Nature's nanofactory. Colloids Surf B Biointerfaces 2009;73:219-23.

20. Raut RW, Lakkakula JR, Kolekar NS, Mendhulkar VD, Kashid SB. 
Phytosynthesis of silver nanoparticle using Gliricidia sepium (Jacq.). Curr Nanosci 2009;5:117-22.

21. Dubey M, Lahtinen M, Sillanpää M. Green synthesis and characterization of silver and gold nanoparticles using leaf extract of Rosa rugose. Colloids Surf A Physiochem Eng Asp 2010;364(1-3):34-41.

22. Jha AK, Prasad K. Green synthesis of silver nanoparticles using Cycas leaf. I J Green Nanotechnol Phys Chem 2010;1(2):110-7.

23. Krishnaraj C, Jagan EG, Rajasekar S, Selvakumar P, Kalaichelvan PT, Mohan N. Synthesis of silver nanoparticles using Acalypha indica leaf extracts and its antibacterial activity against water borne pathogens. Colloids Surf B Biointerfaces 2010;76:50-6.

24. Veerasamy R, Xin TZ, Gunasagaran S, Xiang TF, Yang EF, Jeyakumar N, et al. Biosynthesis of silver nanoparticles using mangosteen leaf extract and evaluation of their antimicrobial activities. J Saudi Chem Soc 2011;15:113-20.

25. Roopan SM, Madhumitha GR, Rahuman AA, Kamaraj C, Bharathi A, Surendra TV. Low-cost and eco-friendly phyto-synthesis of silver nanoparticles using Cocos nucifera coir extract and its larvicidal activity. Ind Crops Prod 2012;43:631-5.

26. Shankar SS, Rai A, Ahmad A, Sastry M. Rapid synthesis of Au, Ag, and bimetallic Au core-Ag shell nanoparticles using Neem (Azadirachta indica) leaf broth. J Colloid Interface Sci 2004;275:496-502.

27. Li S, Shen Y, Xie A, Yu X, Qiu L, Zhang L, et al. Green synthesis of silver nanoparticles using Capsicum aпnиum. Green Chem 2007;9:852-8.

28. Banala RR, Nagati VB, Karnati PR. Green synthesis and characterization of Carica papaya leaf extract coated silver nanoparticles through $\mathrm{X}$-ray diffraction, electron microscopy and evaluation of bactericidal properties. Saudi J Biol Sci 2015;22(5):637-44.

29. Dubey M, Bhadauria S, Kushwah BS. Green synthesis of nanosilver particles from extract of Eucalyptus hybrida (Safeda) leaf. Dig J Nanomater Biostruct 2009;4:537-43.

30. Mittal J, Batra A, Singh A, Sharma MM. Phytofabrication of nanoparticles through plant as nanofactories. Adv Nat Sci Nanosci Nanotechnol 2014;5(4):1-4.

31. Pandey S, Mewada A, Thakur M, Shah R, Oza G, Sharon M. Biogenic gold nanoparticles as fotillas to fire berberine hydrochloride using folic acid as molecular road map. Mater Sci Eng C Mater Biol Appl 2013;33:3716-22.

32. Sathyavathi1 R, Krishna MB, Rao SV, Saritha R, Rao DN. Biosynthesis of silver nanoparticles using Coriandrum sativum leaf extract and their application in nonlinear optics. Adv Sci Lett 2010;3:1-6.

33. Gardea-Torresdey JL, Gomez E, Peralta-Videa JR, Parsons JG, Troiani HY. Process variables in biomimetic synthesis of silver nanoparticles by aqueous extract of Azadirachta indica (Neem) leaves. M J Langmuir 2003;19:237-46.

34. Umashankari J, Inbakandan D, Ajithkumar TT, Balasubramanian T. Mangrove plant, Rhizophora mucronata (Lamk, 1804) mediated one pot green synthesis of silver nanoparticles and its antibacterial activity against aquatic pathogens. Aquat Biosyst 2012;8(1):11

35. Bhattacharya D, Gupta RK. Nanotechnology and potential of microorganisms. Crit Rev Biotechnol 2005;25:199-204.

36. Vankar PS, Bajpai D. Preparation of gold nanoparticles from Mirabilis jalapa flowers. Indian J Biochem Biophys 2010;47:157-60.

37. Shrivastava S, Dash D. Agrifood nanotechnology: A living revolution in food and agriculture. J Nanotechnol 2009;12:240-3.

38. Song JY, Kim BS. Rapid biological synthesis of silver nanoparticles using plant leaf extracts. Bioprocess Biosyst Eng 2009;32:79-84.
39. Mandal S, Rautaray D, Sastry M. Ag+-Keggin ion colloidal particles as novel templates for the growth of silver nanoparticle assemblies. J Mater Chem 2003;13:3002-5.

40. Nandagopal S, Ganesh Kumar A, Dhanalakshmi DP, Prakash P. Bio-prospecting the antibacterial and anticancer activities of silver nanoparticles synthesized using Terminalia chebula seed extract. Int J Pharm Pharm Sci 2014;6(2):368-73.

41. Donda MR, Kudle KR, Alwala J, Miryala A, Sreedhar B, Rudra MP. Synthesis of silver nanoparticles using extracts of Securinega leucopyrus and evaluation of its antibacterial activity. Int J Curr Sci 2013;7:E1-8

42. Sharma S, Kumar S, Bulchandani BD, Taneja S, Banyal S. Green synthesis of silver nanoparticles and their antimicrobial activity against Gram positive and Gram negative bacteria. Int J Biotechnol Bioeng Res 2013;4:711-4.

43. Sulaiman GM, Mohammed WH, Marzoog TR, Al-Amiery AA, Kadhum AA, Mohamad AB. Green synthesis, antimicrobial and cytotoxic effects of silver nanoparticles using Eucalyptus chapmaniana leaves extract. Asian Pac J Trop Biomed 2013;3:58-63.

44. Okafor F, Janen A, Kukhtareva T, Edwards V, Curley M. Green synthesis of silver nanoparticles, their characterization, application and antibacterial activity. Int $\mathrm{J}$ Environ Res Public Health 2013;10:5221-38

45. Karou D, Savadogo A, Canini A, Yameogo S, Montesano C, Simpore J, et al. Antibacterial activity of alkaloids from Sidaacuta. Afr J Biotechnol 2005;4(12):1452-7.

46. Ouda SM. Some nanoparticles effects on Proteus sp. and Klebsiella sp. isolated from water. Am J Infect Dis Microbiol 2014;2(1):4-10.

47. El-Rahman AF, Mohammad TG. Green synthesis of silver nanoparticle using Eucalyptus globulus leaf extract and its antibacterial activity. J Appl Sci Res 2013;9:6437-40.

48. Matsumura Y, Yoshikata K, Kunisaki S, Tsuchido T. Mode of bactericidal action of silver zeolite and its comparison with that of silver nitrate. Appl Environ Microbiol 2003;69:4278-81.

49. Gogoi SK, Gopinath P, Paul A, Ramesh A, Ghosh SS, Chattopadhyay A. Green fluorescent protein-expressing Escherichia coli as a model system for investigating the antimicrobial activities of silver nanoparticles. Langmuir 2006;22:9322-8.

50. Kim SH, Lee HS, Ryu DS, Choi SJ, Lee DS. Antibacterial activity of silver nanoparticles against Staphylococcus aureus and Escherichia coli. Korean J Microbiol Biotechnol 2011;39(1):77-85.

51. Ravishankar RV, Jamuna BA. Nanoparticles and their potential application as antimicrobials. In: Méndez-Vilas A, editor. Science against Microbial Pathogens: Communicating Current Research and Technological Advances. Spain: Formatex Research Center; 2011.

52. Stern JL, Hagerman AE, Steinberg PD, Mason PK. Phlorotanninprotein interactions. J Chem Ecol 1996;22:1877-99.

53. Ayepola OO, Adeniyi BA. The antibacterial activity of leaf extracts of Eucalyptus camaldulensis (Myrtaceae). J Appl Sci Res 2008:4(11):1410-3.

54. Ogundiya MO, Kolapo AL, Okunade MB, Adejumobi J. Evaluation of phytochemical composition and antimicrobial activity of Terminalia glaucescens against some oral pathogens. Adv Nat Appl Sci 2008;2(2):89-93

55. Hazarika D, Phukan A, Saikia E, Chetia B. Phytochemical screening and synthesis of silver nanoparticles using leaf extract of Rhynchote chum ellipticum. Int J Pharm Pharm Sci 2014;6(1):672-4. 